KATARZYNA BORKOWSKA

Instytut Historii Nauki PAN

ORCID: 0000-0002-3963-1569

\title{
Filozofia starożytna a medycyna średniowieczna. Refleksje na marginesie książki Beaty Wojciechowskiej Flebotomia i purgowanie, czyli o leczeniu w wiekach średnich
}

Ancient Philosophy and Medieval Medicine. Reflections on the Margins of Flebotomia i purgowanie, czyli o leczeniu w wiekach średnich [Phlebotomy and purging, or about medical treatment in the Middle Ages]

Summary

The article discusses ancient philosophical sources for humourism. It focuses on the philosophical context described in the first chapter of Beata Wojciechowska's book Flebotomia i purgowanie, czyli o leczeniu w wiekach średnich [Phlebotomy and purging, or about medical treatment in the Middle Ages]. The author briefly points out the differences between the Epicurean, Stoic, Peripatetic and Academic positions on the nature of the soul, its relation to the body and the universe.

Słowa kluczowe: medycyna średniowieczna, filozofia starożytna Key words: medieval medicine, ancient philosophy 
Książka Beaty Wojciechowskiej Flebotomia i purgowanie, czyli o leczeniu $w$ wiekach średnich omawia zabiegi oczyszczające stosowane w średniowieczu (flebotomia i purgowanie) oraz stojącą za nimi postawę teoretyczną wywodzącą się ze starożytności (teoria humoralna). Zestawiając szereg opracowań i najważniejszych źródeł, Autorka w trzech rozdziałach przedstawia syntetyczny obraz teorii i praktyki medycznej średniowiecza. Swoje rozważania rozpoczyna od starożytnych źródeł myśli medycznej średniowiecza w rozdziale pierwszym, główny, środkowy rozdział poświęca zabiegowi upuszczania krwi w wiekach średnich, kończy zaś przeglądowym opisem innych procedur medycznych popularnych w średniowieczu.

Rozdział pierwszy poświęcony został teorii humoralnej, która rozwinęła się na gruncie filozofii starożytnej. Temat wzajemnych związków filozofii i medycyny w starożytnej Grecji Autorka traktuje skrótowo, odsyłając do obszerniejszych opracowań poświęconych temu zagadnieniu. Omawiane koncepcje filozoficzne (człowiek jako mikrokosmos, cztery elementy u podstaw rzeczywistości, wpływ ruchów ciał niebieskich na życie ludzkie) traktuje w sposób ogólny, zacierając różnice w sposobach ich ujęcia przez różnych filozofów ${ }^{1} \mathrm{i}$ bez głębszej refleksji na ich temat. Choć Autorka odsyła do wielu szczegółowych opracowań, a także źródeł (jak choćby Żywotów filozofów Diogenesa Laertiosa, dzieł Arystotelesa i Platona), to jednak głównemu wywodowi można zarzucić brak wnikliwości w omawiane kwestie. Odnosi się ona bezpośrednio jedynie do kilku najważniejszych filozofów (Platon, Arystoteles, Marek Maniliusz), pozostałych zaś traktuje zbiorowo, co prowadzi do pewnych nieścisłości w wywodzie, gdyż interpretacje poszczególnych filozofów znacząco różniły się między sobą. Nie znaczy to, że synteza ich poglądów nie jest możliwa - Cyceron dla przykładu utrzymywał, że najważniejsze greckie szkoły filozoficzne, wyłączając epikureizm, tj. akademicy, perypatetycy i stoicy (czyli szkoły, których przedstawicieli Autorka wyróżniła szczególną uwagą), różnią się między sobą wyłącznie pod względem słów, głoszą jednak te same tezy ${ }^{2}$ - jednak ta zaprezentowana w pierwszym rozdziale książki Beaty Wojciechowskiej zanadto upraszcza sprawę, traktując filozofię starożytną nieco po macoszemu.

1 Na przykład nazywając koncepcję czterech żywiołów Arystotelesowską, gdy w rzeczywistości opracował ją wiek wcześniej Empedokles, a elementów u Arystotelesa było pięć. Zob. np. G.R. Gardina, Empedocles and the Other Physiologists in Aristotle's Physics II 8, "Peitho. Examina Antiqua" 2016, No. 7(1), s. 13-24; R. Janko, Empedocles, On Nature I 233-364: A New Reconstruction of P. Strasb. Gr. Inv. 1665-6, "Zeitschrift Für Papyrologie Und Epigraphik" 2004, t. 150, s. 1-26.

${ }_{2}^{2} \mathrm{~Np}$. Cyceron, Księgi akademickie, I.17-18, I.43; Lukullus 15. 
Budzi wątpliwości na przykład stwierdzenie, że według greckich filozofów „ciało wraz z duszą było zbudowane z tego samego materialnego pierwiastka, z którego stworzony był kosmos"3. W istocie pogląd ów moglibyśmy przypisać zaledwie niewielkiej części starożytnych filozofów i to tych, których Autorka nigdzie nie wspomina z imienia, czyli atomistów: Leucypa ${ }^{4}$, Demokryta ${ }^{5}$, Epikura ${ }^{6}$. Głosili oni bowiem materialność całego świata, w tym w szczególności materialność duszy. W jedność świata i harmonię człowieka z kosmosem bez wątpienia wierzyli stoicy reprezentowani w pierwszym rozdziale Flebotomii... przez Marka Maniliusza. Problematyczne jest jednak przypisywanie im poglądu o materialnym charakterze duszy. Jak pisze Diogenes Laertios: „Wedle stoików we wszechświecie istnieją dwie zasady (á $\rho \chi \alpha i)$ :

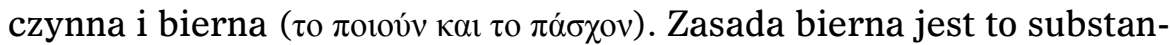
cja bezjakościowa - materia, zasada czynna, to tkwiący w niej rozum ( $\lambda$ ó $о$ s) - bóg. On bowiem, będąc wiecznym, z całego zasobu materii tworzy wszystkie rzeczy. Naukę tę głosi Zenon z Kition w rozprawie $O$ istocie, Kleantes w rozprawie $O$ atomach, Chryzyp w końcu pierwszej księgi Fizyki, Archedemos w rozprawie O elementach, Poseidonios w drugiej księdze Fizyki. Istnieje - ich zdaniem - różnica mię-

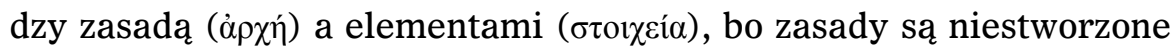
i niezniszczalne, elementy zaś ulegają zniszczeniu przez zognienie

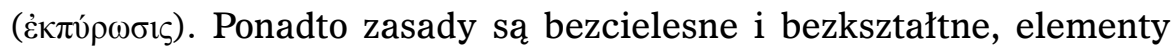
zaś mają kształty. Ciało, jak mówi Apollodor w Fizyce, jest tym, co

${ }^{3}$ B. Wojciechowska, Flebotomia i purgowanie, czyli o leczeniu $w$ wiekach średnich, Kielce 2019, s. 15-16.

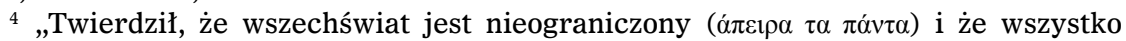
przechodzi w siebie nawzajem; Całość ( $\tau$ o $\pi \alpha v$ ) obejmuje próżnię i pełnię [czyli atomy]. Światy powstają z ciałek [czyli atomów, $\sigma \omega ́ \mu \alpha \tau \alpha$ ] wpadających w próżnię i wzajemnie się sczepiających" - Diogenes Laertios, Żywoty i poglądy sławnych filozofów, przeł. I. Krońska, Warszawa 1982, Leucyp, IX.6.30, s. 524-525.

${ }^{5}$ Na przykład „Poglądy zaś jego były następujące: Początkiem wszechrzeczy są ato-

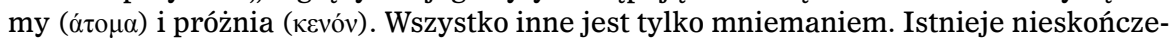
nie wiele światów, które rodzą się i giną. Nic nie może powstać z niebytu ani w niebyt się obrócić. Atomy są nieskończone pod względem wielkości i ilości, a poruszają się we wszechświecie ruchem wirowym; $w$ ten sposób powstają wszystkie ciała złożone, jak ogień, woda, powietrze, ziemia; albowiem i one są konglomeratami określonych atomów. Atomy dzięki swej masywności nie podlegają jakiemukolwiek oddziaływaniu ( $\alpha \pi \alpha \theta \eta ́)$ i są niezmienne ( $\alpha v \alpha \lambda \lambda$ oí $\omega \tau \alpha)$. Słońce i księżyc składają się z atomów gładkich i okrągłych, podobnie jak dusza. Dusza ( $\psi v \chi \eta ̛)$ jest tym samym co umysł (vouৎ)" - ibidem, Demokryt, IX.7.44, s. 532.

${ }^{6} \mathrm{~Np}$, „Z kolei w oparciu o wrażenia zmysłowe i czucia - bo w ten sposób zdobędziemy niewzruszoną podstawę pewności - dojdziemy do przekonania, że dusza jest ciałem złożonym z cząstek subtelnych rozproszonych po całym ciele, które można najtrafniej przyrównać do tchnienia przenikniętego ciepłem" - ibidem, Epikur, X.1.63., s. 605. 
ma trzy wymiary: długość, szerokość i głębokość: to się nazywa także ciałem stałym" ". Wedle sprawozdania Diogenesa Laertiosa stoicy wyraźnie oddzielali materialną część świata od niematerialnej. Ciało i dusza tworzą razem harmonijną całość, nie są jednak zbudowane $\mathrm{z}$ tego samego pierwiastka. Relacja człowieka z kosmosem wynika raczej z powinowactwa materialnej części świata z ludzkim ciałem oraz rozumnej (lub boskiej) części świata z duszą ludzką. „Bóg jest tym samym co rozum (voṽ $)$, przeznaczenie ( cze wiele innych nazw. (...) Świat jest kierowany przez rozum (voṽs)

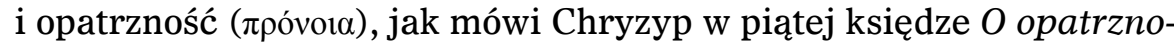
ści i Poseidonios w trzeciej księdze $O$ bogach, bo rozum przenika każdą jego część, podobnie jak dusza w człowieku"8. Mimo tych wyraźnych rozróżnień stoicy uważani są powszechnie za wyznawców materializmu ${ }^{9}$, co zapewne leży u źródeł perspektywy przedstawionej przez Wojciechowską. Kwestia materialności duszy w filozofii stoickiej jest jednak bardziej skomplikowana. Dusza nie istnieje wprawdzie poza ciałem, ale przenika je i nadaje mu moc odczuwania. Perspektywa ta ma wiele wspólnego z fizyką Arystotelesa, również uważanego przez filozofów za materialistę ${ }^{10}$. Jego materializm nie polega jednak na przyznaniu duszy i ciału jednakowej, materialnej istoty, a na odrzuceniu faktycznego rozdziału na duszę i ciało, ponieważ jedynie dusza istniejąca w ciele leży w granicach ludzkiego doświadczenia i poznania ${ }^{11}$. „Każde ciało uczestniczące w życiu jest substancją złożoną. Skoro zatem ciało jest tego rodzaju - ma bowiem w sobie życie - dusza nie może być ciałem. Ciało nie należy bowiem do rzeczy nadających kształt, jest raczej obiektem kształtowania - materią. Wynika zatem z konieczności, że dusza musi być substancją jako forma ciała ma-

7 Ibidem, Zenon z Kition, VII.1.134-135, s. 425.

${ }^{8}$ Ibidem, VII.1.136-138, s. 425-426.

${ }^{9} \mathrm{Na}$ przykład ,W związku z tym, iż stoicy odrzucili to, co duchowe, a swoje teorie opierali wyłącznie na istnieniu bytów cielesnych, wszystko co istnieje jest na wskroś materialne: Bóg, świat, dusza, dobro, wiedza itp. Monizm stoicki znajduje odzwierciedlenie przede wszystkim w rozumieniu świata jako jedności - to, co jest «rzeczywiste» jest jedną i tą samą substancją - Naturą" - H. Wiśniewski, W zdeterminowanym świecie. O stoickiej sile rzadzacej kosmosem, „Zeszyty Naukowe KUL” 2016, t. 59 nr 2, s. 48, por. D. Baltzly, Stoicism, “The Stanford Encyclopedia of Philosophy”, wiosna 2019, plato.stanford.edu/archives/spr2019/entries/stoicism/ [dostęp: 3.06.2021].

${ }_{10}$ Np. L.S. Carrier, Aristotelian Materialism, "Philosophia" 2006, 34, s. 253-266, DOI: $10.1007 / \mathrm{s} 11406-006-9033-9$.

11 C. Shields, Aristotle's Psychology, "The Stanford Encyclopedia of Philosophy", zima 2020, plato.stanford.edu/archives/win2020/entries/aristotle-psychology/ [dostęp: 1.06.2021]. 
terialnego mającego potencjalność życia"12. Forma jako element rzeczywistości współistniejący z materią oraz koncepcja potencjalności pozwoliła Arystotelesowi wyjaśnić zachodzenie zmiany ${ }^{13}$, która w ujęciu parmenidejsko-platońskim kłóciła się z istnieniem, postrzeganym $\mathrm{w}$ sensie idealnym jako wieczne i niezmienne ${ }^{14}$. Stanowiska stoików i Arystotelesa, skupione na aspekcie materialnym, ale uwzględniające odmienny charakter istoty duszy, niosą w sobie ślad myśli platońskiej, z której czerpią źródło ${ }^{15}$, oba jednak polemizują z idealizmem Platona, dla którego dusza może istnieć poza ciałem, a wręcz jest to jej naturalny $\operatorname{stan}^{16}$. W przeciwieństwie do swoich następców Platon wyobrażał sobie rzeczywistość duchową oddzieloną od materialnej i pierwotną wobec niej. Mimo tego Cyceron uważa wszystkie trzy szkoły w gruncie rzeczy za tożsame. „Platon (...) pozostawił po sobie najdoskonalszą naukę (perfectissimam disciplinam) perypatetyków i akademików, którzy różnią się w nazwach, a zgadzają się co do rzeczy, i od których sami stoicy różnią się w słowach raczej niż w poglądach" ${ }^{17}$. Tożsamość ta, jeśli ją przyjmiemy, nie objawiałaby się jednak w materializmie, a w wierze w immanentny porządek kosmosu, w której człowiek zajmuje nieprzypadkowe miejsce. Wprawdzie zdanie Wojciechowskiej, $\mathrm{w}$ polemice $\mathrm{z}$ którym pozostają powyższe uwagi, nie stanowi bynaj-

${ }_{12}$ Arystoteles, $O$ duszy, red. W.D. Ross, Oxford 1956, I.412a, tłumaczenie własne.

${ }^{13}$ A. Chalmers, Atomism in its Ancient Greek Perspective, "Boston Studies in the Philosophy of Science. The Scientist's Atom and the Philosopher's Stone” 2009, t. 279, s. 59-74.

${ }^{14} \mathrm{~Np}$. „Czym jest to, co istnieje wiecznie, nie mając początku? Czym zaś jest to, co wciąż na nowo powstaje, lecz nie istnieje wcale? To pierwsze pojąć można rozumem, zawsze pozostaje tym samym. Drugie tworzy mniemania poprzez bezrozumne doznania, rodząc się i ginąc, nigdy nie istnieje naprawdę" - Platon, Timajos, [w:] J. Burnet (red.), Platonis Opera, Oxford 1903, 27d-28a, tłumaczenie własne.

${ }^{15}$ Np. por. powyższy ustęp z Arystotelesa do następujących słów Platona: „Każde ciało, które czerpie ruch z zewnątrz, pozbawione jest duszy, to zaś, które porusza się samo siłą z wewnątrz, musi mieć duszę, taka bowiem jest natura duszy; (...) istotą żywą nazywa się całość złożoną z duszy i ciała, dalej zwaną śmiertelną" - Platon, Fajdros, [w:] J. Burnet (red.), Platonis Opera, Oxford 1903, 245e-246c, tłumaczenie własne.

${ }^{16} \mathrm{~Np}$. Platon, Fajdros 245c-257a; Fedon, 64a.

${ }_{17}$ Cyceron, Lukullus, red. O. Plasberg, Leipzig 1922, 15; por. „Pod wpływem Platona, którego dorobek był różnorodny, wszechstronny i obfity, powstała jedna i zgodna forma filozofii pod dwiema nazwami: akademików i perypatetyków, którzy, zgadzając się co do rzeczy, różnili się w kwestii terminów. (...) Początkowo była to w rzeczy samej jedność pod dwoma imionami; niczym bowiem nie różniły się od siebie szkoła perypatetyków i tamta stara Akademia” - Cyceron, Księgi akademickie I.17-18; „Krótko wprawdzie i bardzo jasno wyłożona została (...) przez ciebie, Warronie, nauka i starej Akademii, i stoików, moim jednak zdaniem, jak podobało się naszemu przyjacielowi Antiochowi, ich doktrynę należy traktować raczej jako poprawkę starej Akademii niż coś nowego" - tamże I.43, tłumaczenie własne. 
mniej kluczowego punktu jej wywodu, zaciemnia ono jednak obraz filozofii starożytnej, dla którego przybliżenia napisała przecież pierwszy rozdział swojej książki.

Więcej szczegółów na temat różnic między poszczególnymi szkołami filozoficznymi oczekiwalibyśmy przede wszystkim, gdy czytamy, że Hipokrates połączył „poglądy jońskich filozofów przyrody z teoriami Pitagorasa i jego ucznia Alkmeona z Krotonu oraz Empedoklesa z Akragas" ${ }^{18}$. Poglądy te pozostają niestety niewspomniane, w związku z czym nie wiemy, na czym konkretnie polegała synteza Hipokratesa. Pozostaje nam sięgnąc do pozycji wymienionych w przypisach (G. Reale, Historia filozofii starożytnej; W. Sady, Dzieje religii, filozofii i nauki. Od Talesa z Miletu do Mahometa, Diogenes Laertios, Żywoty filozofów). Przy omawianiu koncepcji Hipokratesa Autorka nie odwołuje się do źródeł, lecz do pojedynczego opracowania (J. Krajewska, A. Głusiuk, Epidemie. Księgi I i III Hipokratesa oraz $w$ greckiej i rzymskiej historiografii od starożytności do wczesnego średniowiecza). Podobnie opisując system Galena, opiera się na opracowaniach (tym razem w liczbie mnogiej - A. Bednarczyk, Galen, gtówne koncepcje systemu filozoficzno-lekarskiego, A. Pacewicz, Galen o naturze wiedzy medycznej), nie odnosząc się bezpośrednio do tekstu Galena.

Rozważania o filozofii i medycynie starożytnej nie są jednak głównym przedmiotem książki. Gdy Autorka przechodzi do omawiania spuścizny średniowiecza, jej dyskurs staje się znacznie silniej zakorzeniony w źródłach i znacznie bardziej konkretny. Przedstawiając autorów średniowiecznych kontynuujących grecką tradycję teorii humoralnej, odwołuje się już do konkretnych tekstów (Izydor z Sewilli, Etymologie, Beda Venerabilis, De temporum ratione, Hildegarda $\mathrm{z}$ Bingen, Causae et curae, Wilhelm z Conches, Philosophia mundi). Nie wgłębia się w nie jednak zanadto, traktuje je pobieżnie. Bardzo szczegółowo omawia natomiast zagadnienia znajdujące się w Kanonie Awicenny. Autorka przywołuje obszerną literaturę poświęconą perskiemu uczonemu. Kolejne 25 stron stanowi szczegółowy opis teorii humoralnej wedle Kanonu Awicenny. Autorka śledzi tutaj blisko tekst pierwszej księgi Kanonu, relacjonując jego treści rozdział po rozdziale, a niekiedy strona po stronie, i cytując długie ustępy po łacinie w przypisach.

Rozdział dotyczący flebotomii opisuje zabieg upuszczania krwi w pismach dawnych autorów medycznych, od Galena po Michała Fal-

${ }^{18}$ B. Wojciechowska, op. cit., s. 16. 
kenera z Wrocławia. Znakomita większość tego rozdziału, podobnie jak poprzedniego, poświęcona jest twórczości Awicenny (s. 62-80). Autorka szczegółowo omawia aspekty zabiegu poruszane przez Awicennę, takie jak: cel i charakter zabiegu, wskazania, przeciwwskazania, odpowiedni czas i sposób przeprowadzania zabiegu, czynności pomocnicze przed zabiegiem i po nim, specyfika nacinania konkretnych żył, a także przyrządy potrzebne do wykonania zabiegu. Po opisie różnych aspektów flebotomii z Kanonu Awicenny Autorka wspomina pokrótce kilka dzieł średniowiecznych, których autorzy odwoływali się do niego, pisząc o flebotomii: Henryk z Winchesteru, Tractatu de aegritudinis flebotomandis, Walter Angilonis, Summa medicinalis, Jan de Sancto Amando, Expositio supra Antidotarium Nicolai, Arnold de Villanova, Opera omnia medica, Bernard de Gordon De phlebotomia, Guy de Chauliac, Chirurgia magna. Pismom tym nie poświęca się wiele miejsca, jednak większość z nich zostaje bezpośrednio dopuszczona do głosu dzięki zamieszczonym cytatom. $Z$ większą dokładnością omawia Autorka teksty Tomasza z Wrocławia, Křištana z Prachatic oraz Giovanniego dell'Aquila, każdemu z nich poświęcając po kilka stron. Omawiając De phlebotomia et de iudiciis cruoris Tomasza z Wrocławia, Autorka skupia się na sposobach cięcia odpowiadających różnym dolegliwościom, diagnozie na podstawie koloru krwi, uwydatniając praktyczny charakter dzieła. De sanguis minucione Křištana z Prachatic Autorka także umieszcza w nurcie pragmatyczno-medycznym. Traktat ów zawiera wskazówki na temat odpowiedniego wykonania cięcia, stosownych narzędzi; największy nacisk kładzie jednak na odpowiednią porę wykonania zabiegu. Křsištan z Prachatic zwracał wielką uwagę na związek zdrowia ludzkiego z ruchami ciał niebieskich, których szczegółową obserwację zalecał, aby przeprowadzić flebotomię w sprzyjającym okresie. Wreszcie Wojciechowska poświęca parę stron na omówienie napisanego heksametrem poematu De phlebotomia autorstwa Giovanniego dell'Aquila, który spełniać miał funkcję mnemoteczniczną. Autorka zestawia teksty pisarzy medycznych czasów średniowiecza; ze względu na charakterystyczną cechę umysłowości średniowiecza, jaką było przywiązanie do autorytetu, nie znajdziemy wielkich różnic między postawami reprezentowanymi przez owych autorów, z których wszyscy podążają szlakiem wyznaczonym przez Awicennę. Wojciechowska nie poświęca też wiele uwagi śledzeniu odstępstw czy ulepszeń późniejszych tekstów w stosunku do Kano$n u$. Pisze ona przede wszystkim o tym, co na temat flebotomii możemy znaleźć u którego pisarza średniowiecznego. Kwestia relacji między 
tymi tekstami, poza krótkimi wtrąceniami typu „za Awicenną”, pozostaje nieporuszona.

Ostatni rozdział, zatytułowany Purgowanie i inne środki lecznicze, obejmuje przegląd różnych zabiegów leczniczych, przy czym duża jego część poświęcona jest substancjom leczniczym. Podobnie jak w poprzednim rozdziale, głównym źródłem pozostaje Awicenna (s. 111-128). Na podstawie jego Kanonu Autorka omawia środki lecznicze oraz zabiegi: kąpiele ciepłe i zimne, prowokowanie wymiotów, stawianie baniek, posługiwanie się pijawkami, przyżeganie. Niekiedy trudno się rozeznać, czy Autorka odnosi się do konkretnego tekstu, czy też opisuje ogólny konsensus medycyny średniowiecznej na dany temat. Dzieje się tak na przykład przy temacie wymiotów ${ }^{19}$. Wojciechowska zaczyna od Awicenny („Awicenna zaznaczał, iż ludzie często unikają wymiotów z powodu swojej natury...”20), nie podając jednak przypisów przez całe dwie strony. Jej narracja zmienia się w trakcie - nie wspomina już Awicenny, używa za to form bezosobowych (,powinno się”, „uważano”, „należało”, „odradzano”). Wydaje się, że Wojciechowska tworzy tutaj syntetyczny obraz zabiegu oczyszczania przez wymioty na podstawie różnych źródeł, tworząc spójny obraz z wiadomości w nich zawartych. Jest to jednak tylko podejrzenie, gdyż cały wywód dotyczący wywoływania wymiotów pozbawiony jest przypisów. Dopiero w ostatnim akapicie na temat oczyszczania przez wymioty Autorka powraca do dzieła Awicenny (,Awicenna zakazywał leczenia wymiotów z flebotomią, którą zalecał odłożyć o trzy dni”" ${ }^{11}$ ). Dowiadujemy się wówczas, że perski uczony zalecał przemyć usta octem rozcieńczonym $\mathrm{w}$ wodzie, a także wypić napój z żywicy drzewa mastyksowego i wody z jabłek, a także powstrzymać się od jedzenia i picia wody. Tymczasem zalecenia o nieznanej proweniencji, na które powołuje się Autorka na s. 118-119, wspominają o piciu wody różanej oraz posiłku złożonego z gotowanego kurczęcia i wina. $\mathrm{Z}$ nieco większą dokładnością potraktowany jest temat stawiania baniek, gdzie znajdziemy mnogość różnorodnych przypisów, tak że łatwo nam zidentyfikować, skąd zaczerpnięte są informacje przedstawiane w książce. Autorka przytacza pokrótce słowa Guya de Chauliaca, Křištana z Prachatic, Bernarda de Gordon. O wiele więcej szczegółów i odniesień do konkretnych tekstów znajdziemy w drugiej części rozdziału, poświęconej stosunkowi lekarza do pacjenta oraz diecie te-

\footnotetext{
${ }^{19}$ Ibidem, s. $118-120$.

${ }^{20}$ Ibidem, s. 118.

${ }^{21}$ Ibidem, s. 120.
} 
rapeutycznej. Pisząc o odpowiednim podejściu do pacjenta, Autorka opiera się na anonimowych traktatach ze szkoły medycznej w Salerno (Quomodo visitare debes infirmum, De adventu medici ad aegrotum). Na znacznie większą różnorodność źródeł powołuje się Autorka przy omawianiu diety terapeutycznej. Wojciechowska przytacza dokładne zalecenia dietetyczne zależnie od dolegliwości, kompleksji, pory roku i wieku, pokrótce omawiając kilka tekstów (Piotr Musandini z Salerno, Tractatulus de cibis et de potibus febricitantium, Mikołaj Praepositus z Salerno, Antidotarium, Hildegarda z Bingen, Causae et curae, Jan XXI, Kompendium medycyny naturalnej). Na dłużej zatrzymuje się przy Speculum naturale Wincentego z Beauvais, którego zaleceniom na temat lekarstw (tudzież posiłków o charakterze prozdrowotnych) pochodzenia zwierzęcego poświęca 8 stron (s. 146-154).

Książka Beaty Wojciechowskiej traktuje o medycynie średniowiecznej w sposób przeglądowy. Rozpoczynając rozdziałem o źródłach średniowiecznych koncepcji medycznych w filozofii starożytnej, przedstawia ona uproszczoną syntezę myśli starożytnych filozofów. Choć mogłaby ona być bardziej wnikliwa, spełnia jednak swoją funkcję - wprowadzenia do teorii humoralnej, będącej podstawą medycyny średniowiecznej. Wojciechowska przywołuje szereg opracowań przybliżających omawiane przez nią tematy, a także przywołuje źródła dawne. Jej głównym punktem odniesienia jest Kanon Awicenny, co nie zaskakuje, zważywszy, że był on najbardziej poczytnym tekstem medycznym w wiekach średnich. Oprócz tego Autorka przytacza szereg późniejszych pism, traktujących o tych samych zagadnieniach, co Awicenna. Pisma te omawiane są w sposób sprawozdawczy, bez refleksji na temat rozwoju myśli medycznej na przestrzeni niemal tysiącletniej epoki, a także bez szerszego komentarza na temat uwarunkowań kulturowych tejże myśli. Książka Flebotomia i purgowanie, czyli o leczeniu $w$ wiekach średnich relacjonuje treści wybranych tekstów, pozostawiając głębszą analizę i refleksję nad nimi w gestii czytelnika. Jak twierdzi Autorka, ,praca ta nie pretenduje do ukazania wszystkich problemów związanych ze średniowieczną medycyną. Stanowi raczej przyczynek do dalszych analitycznych rozważań na temat teoretycznych podstaw i praktycznych metod leczenia w wiekach średnich”. 